\title{
Drgania mechaniczne w procesach spawalniczych
}

\section{Mechanical vibrations in the welding processes}

\section{Streszczenie}

W artykule przedstawiono aktualny stan zagadnienia dotyczący wspomagania klasycznych procesów spawalniczych drganiami mechanicznymi. Omówiono także wybrane wyniki prac własnych w zakresie wpływu drgań mechanicznych na budowę i właściwości struktur spawalniczych.
Abstract

The current state of knowledge of the mechanical vibration supporting conventional welding processes was presented. The self research results according to mechanical vibration influent on structure and properties of weIding joints were also described.

\section{Wstęp}

Współcześnie drgania mechaniczne znajdują zastosowanie w wielu procesach wytwarzania. Najważniejsze $z$ nich to metalurgia, klejenie, zgrzewanie ultradźwiękowe, lutowanie i w ograniczonym zakresie procesy spawania. Najczęściej ich częstotliwość mieści się w przedziale $20 \div 100000 \mathrm{~Hz}$. Drgania o niskiej częstotliwości rzadko można spotkać w zastosowaniach technologicznych. Fale ultradźwiękowe stosuje się za to znacznie częściej w procesie zgrzewania i w celach diagnostycznych. Są one ważnym narzędziem współczesnej inżynierii materiałowej, elektrotechniki i telekomunikacji i wykorzystuje się je w wielu gałęziach przemysłu oraz medycynie, wciąż znajdując nowe zastosowania. Zastosowanie drgań ultradźwiękowych do wspomagania konwencjonalnych procesów spawalniczych nie jest już tak powszechne. Dzieje się tak z kilku powodów. Pierwszy z nich dotyczy problemu technicznego $z$ wprowadzaniem drgań w pobliżu strefy wysokiej temperatury, jaka towarzyszy procesom spawania i procesom metalurgicznym. Kolejny problem to brak informacji o charakterystyce rzeczywistego widma drgań w miejscu spawania, jakie powstają w konkretnym układzie geometrycznym złożonym przykładowo z ukosowanych elementów łączonych. Ponadto postać wprowadzanych drgań ulega ciągłej przemianie przy przejściu z fazy stałej do ciekłej i odwrotnie. Wpływ tych zjawisk na strukturę

Dr inż. Arkadiusz Krajewski - Politechnika Warszawska. i właściwości złączy nie został jeszcze dostatecznie poznany. Dlatego ocena, czy efekty uzyskane w wyniku zastosowania drgań mechanicznych będą korzystne, czy nie, zależeć będzie od wzajemnego usytuowania elementów łączonych, podatności spawanego materiału na sprężyste oraz niesprężyste oddziaływanie struktury, a także od parametrów i rodzaju drgań. $Z$ tych powodów zastosowanie drgań mechanicznych zniechęca potencjalnych badaczy do prowadzenia prac nad ich oddziaływaniem ze środowiskiem spawanym. Trudności te nie powinny jednak być powodem do zaniechania prac badawczych w tym zakresie, gdyż potencjalne korzyści płynące ze wspomagania procesów spawalniczych drganiami mechanicznymi są niezwykle obiecujące. Wielu badaczy uzyskało znaczącą poprawę właściwości mechanicznych i strukturalnych złączy spawanych w procesie wspomaganym drganiami mechanicznymi.

Zastosowanie drgań mechanicznych w metalurgii i spawalnictwie można rozpatrywać w kilku aspektach: poprawiania struktury w procesie rafinacji i krzepnięcia, odzysku stopów z żużli piecowych, czyszczenia powierzchni i rozpraszania zarodników krystalizacji, poprawiania zwilżalności w procesach lutowania, rozdrobnienia ziarna i poprawy właściwości mechanicznych złączy spawanych. Umiejętne zastosowanie drgań mechanicznych w procesach zgrzewania rezystancyjnego czy dyfuzyjnego może także przyczynić się do poszerzenia strefy dyfuzji w stanie stałym pomiędzy łączonymi materiałami. Ponadto drgania mechaniczne można wykorzystać do podniesienia poziomu energii układu powyżej energii aktywacji procesu spajania, czy wreszcie do odprężania wibracyjnego złączy spawanych. 


\section{Zastosowanie drgań w metalurgii}

Już w 1930 r. w opisano zastosowania drgań w metalurgii i odlewaniu szkliw, z czego wynika, że oddziałują one zarówno $w$ fazie ciekłej, na etapie krzepnięcia, jak i w fazie stałej [1]. Podczas oddziaływania drgań na płynne stopy uzyskuje się pozytywne efekty w postaci odgazowania i lepszej spoistości, minimalizując zjawisko powstawania jam skurczowych. Ponadto, przez wprowadzanie drgań można doprowadzić do wytworzenia stopów metali, które nie tworzą roztworów ciągłych, np. Al-Cd, Al-Pb, Fe-Pb oraz $\mathrm{Zn}-\mathrm{Pb}$.

Podczas krzepnięcia wprowadzane drgania mechaniczne powodują rozdrobnienie ziarna i poprawiaja jednorodność materiału $[1 \div 20]$. Wytłumaczenia tego zjawiska upatruje się w występowaniu niszczących sił tarcia pomiędzy powstającymi krystalitami a roztopionym metalem.

W fazie stałej drgania mechaniczne mogą wpłynąć na osłabienie struktury i wywołać przykładowo sztuczne starzenie. Stwierdzono także istotny wpływ drgań na właściwości magnetyczne ferromagnetyków, objawiający się wzmocnieniem magnesowania i jednoczesnym zmniejszeniem magnetyzmu szczątkowego. Procesy te są częściowo nieodwracalne, co wskazuje na zmianę struktury wewnętrznej. Można je zaobserwować np. w stali, gdzie wskaźnikiem zmian strukturalnych jest przyspieszona dyfuzja azotu wywołana osłabieniem struktury [12].

Energia drgań mechanicznych, wprowadzanych do ciekłego stopu, wywołuje dwa rodzaje zjawisk: natury mechanicznej, które niszczą front krystalizacji i zwiększają liczbę zarodków, oraz natury energetycznej, które powodują wzrost energii wewnętrznej

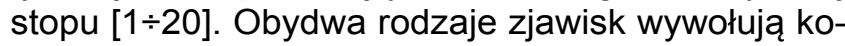
rzystną modyfikację mechanizmu krystalizacji stopu, powodując zmniejszenie przechłodzenia, skrócenie czasu krystalizacji, rozdrobnienie struktury i zmianę kinetyki krystalizacji stopu oraz skrócenie czasu ewentualnych przemian fazowych w stanie ciekłym. Mechanizm oddziaływania drgań nie zależy istotnie od częstotliwości w stosowanym zakresie $(20 \div 20000 \mathrm{~Hz})$, a jedynie od energii drgań wprowadzonej do jednostkowej objętości cieczy.

W literaturze [21 $\div 23$ ] przedstawiono próby wprowadzania podłużnych drgań ultradźwiękowych o częstotliwości $20 \mathrm{kHz}$ i mocach: 400, 500, 600 i $700 \mathrm{~W}$ do ciekłej stali $1 \mathrm{Cr} 18 \mathrm{Ni9Ti}$. Uzyskano zwiększenie wytrzymałości i rozdrobnienie struktury podczas zastosowania drgań ultradźwiękowych, przy czym wzrost ten był tym większy, im bliżej przetwornika ultradźwiękowego znajdowała się badana próbka. Wysnuto wniosek, że głównym czynnikiem, od którego zależy efektywne oddziaływanie na ciekły stop, jest chwilowa wartość ciśnienia akustycznego. Im jest ono większe, tym bardziej znaczące zmiany zachodzą podczas krzepnięcia stopu.

\section{Drgania mechaniczne w procesach spawalniczych}

W procesach spawania występują istotne ograniczenia w stosowaniu drgań mechanicznych o częstotliwościach ultradźwiękowych. Wynikają one z następujących powodów:

- technicznych trudności z wprowadzeniem drgań do ciekłego metalu przy wysokiej temperaturze źródła ciepła z wyjątkiem zastosowania lasera jako źródła ciepła oraz drgań jednocześnie [24],

- ograniczonego oddziaływania drgań na skutek zmian ciśnienia akustycznego fali wraz z oddalaniem się od źródła drgań [21],

- problem synchronizacji momentu oddziaływania drgań w stosunku do odpowiednich faz krzepnięcia jeziorka spawalniczego od czego zależy rodzaj oddziaływania drgań z fazą ciekłą lub stałą [25],

- zagrożenia rozproszenia (wyrzutu) jeziorka ciekłego metalu w efekcie powstawania kawitacji i naruszenia sił spójności fazy ciekłej [26],

- trudności z wprowadzaniem drgań ultradźwiękowych do elementów cienkich o niewystarczającej sztywności oraz złożonej geometrii [1].

Już $w$ pod koniec lat 50. XX w. przeprowadzono badania potwierdzające korzystny wpływ drgań niskiej częstotliwości na strukturę i właściwości złączy spawanych ze stopu aluminium Al-Mg [26, 27]. Autorzy tych prac sformułowali na podstawie wyników swoich badan stwierdzenie, że oddziaływanie tego typu drgań na krystalizujące jeziorko przejawia się w:

- zmianie procesu krystalizacji przez rozdrobnienie struktury pierwotnej i uzyskanie w ten sposób polepszenia właściwości mechanicznych,

- zwiększeniu stopnia odgazowania płynnego jeziorka, co objawiaj się zmniejszeniem pęcherzy i porów,

- równomiernym rozmieszczeniu wtrąceń niemetalicznych i uzyskaniu bardziej jednolitego składu chemicznego w spoinie.

Wykonane pomiary wielkości ziarna wykazały, że zależy ono od amplitudy drgań (rys. 1).

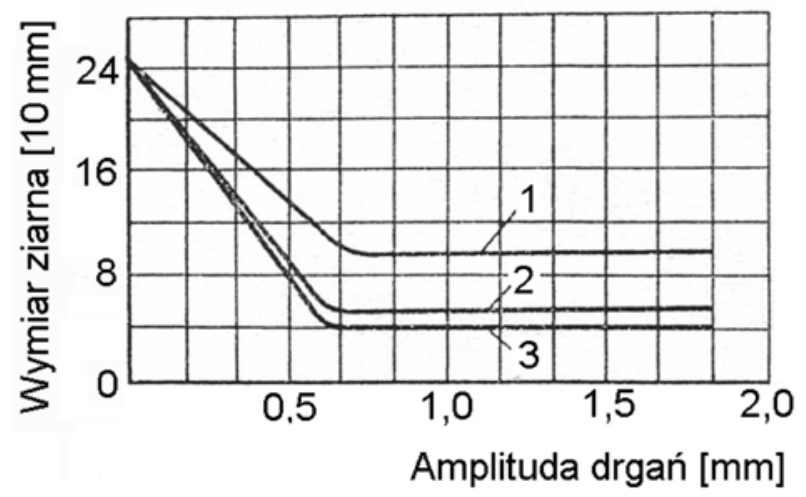

Rys 1. Wpływ częstotliwości i amplitudy drgań na wielkość ziarna przy spawaniu stopów lekkich typu Al-Mg: $1-25 \mathrm{~Hz}, 2-47 \mathrm{~Hz}$, $3-55 \mathrm{~Hz}[26]$

Fig. 1. Frequency and amplitude of vibration - grain size relationship during Al-Mg alloys welding: $1-25 \mathrm{~Hz}, 2-47 \mathrm{~Hz}, 3-55 \mathrm{~Hz}$ [26] 
Zmniejszenie wielkości ziarna przekłada się na właściwości mechaniczne (rys. 2).

Spawanie z oddziaływaniem drgań niskiej częstotliwości zaleca się stosować do wykonywania konstrukcji lekkich i odpowiedzialnych z zastosowaniem stołów wibracyjnych o częstotliwości drgań od 50 do $600 \mathrm{~Hz}$, wytwarzających drgania o amplitudzie od 0,2 do $2 \mathrm{~mm}$. Korzystne efekty uzyskuje się, a)

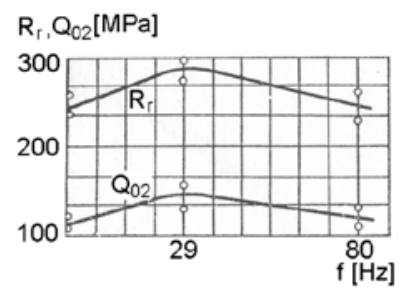

b)

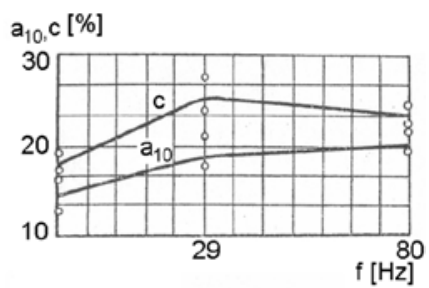

Rys. 2. Wpływ parametrów drgań o niskiej częstotliwości na właściwości mechaniczne napoiny przy amplitudzie 1,2 mm: a) wytrzymałość, b) plastyczność [27]

Fig. 2. Relationship between low frequency vibration parameters and weld mechanical properties for constant amplitude $1,2 \mathrm{~mm}$ : a) strength, b) plasticity [27] spawając metodami automatycznymi w pozycji podolnej, przy możliwie dużej objętości jeziorka.

Interesujące wyniki badań otrzymano, stosując drgania mechaniczne o niskiej częstotliwości w czasie spawania łukowego GTAW [28]. W badaniach zastosowano stop niklu $690 \mathrm{w}$ formie blach o wymiarach $150 \times 100 \times 8,7 \mathrm{~mm}$. Proces spawania prowadzono, stosując materiał dodatkowy INOCEL $82 \mathrm{w}$ postaci drutu o średnicy $1,2 \mathrm{~mm}$.

Drgania mechaniczne wprowadzono za pomoca układu Meta-Lax 1701-1F firmy Bonal Technologies. Zmierzona częstotliwość rezonansowa układu wynosiła $58 \mathrm{~Hz}$. Badania procesu spawania, prowadzono przy częstotliwości $0 \mathrm{~Hz}, 48 \mathrm{~Hz}$ oraz częstotliwości rezonansowej $58 \mathrm{~Hz}$. Wibracje wprowadzono przez wirujący element mimośrodowy, stosując, siły o wartościach 0,376 i $496 \mathrm{~N}$ przy odpowiadającym im amplitudom drgań 0,48 oraz $58 \mu \mathrm{m}$.

W wyniku zastosowania drgań mechanicznych niskiej częstotliwości uzyskano rozbicie dendrytów, a otrzymana struktura wykazywała większą równomierność budowy ziarnowej oraz zmniejszenie ich rozmiarów (rys. 3).
Rys. 3. Schemat stanowiska do badań eksperymentalnych spawania z udziałem drgań mechanicznych niskiej częstotliwości oraz wyniki uzyskanych badań [28]

Fig. 3. Statement for welding supported by a low frequency vibration and results of the experimental work [28]
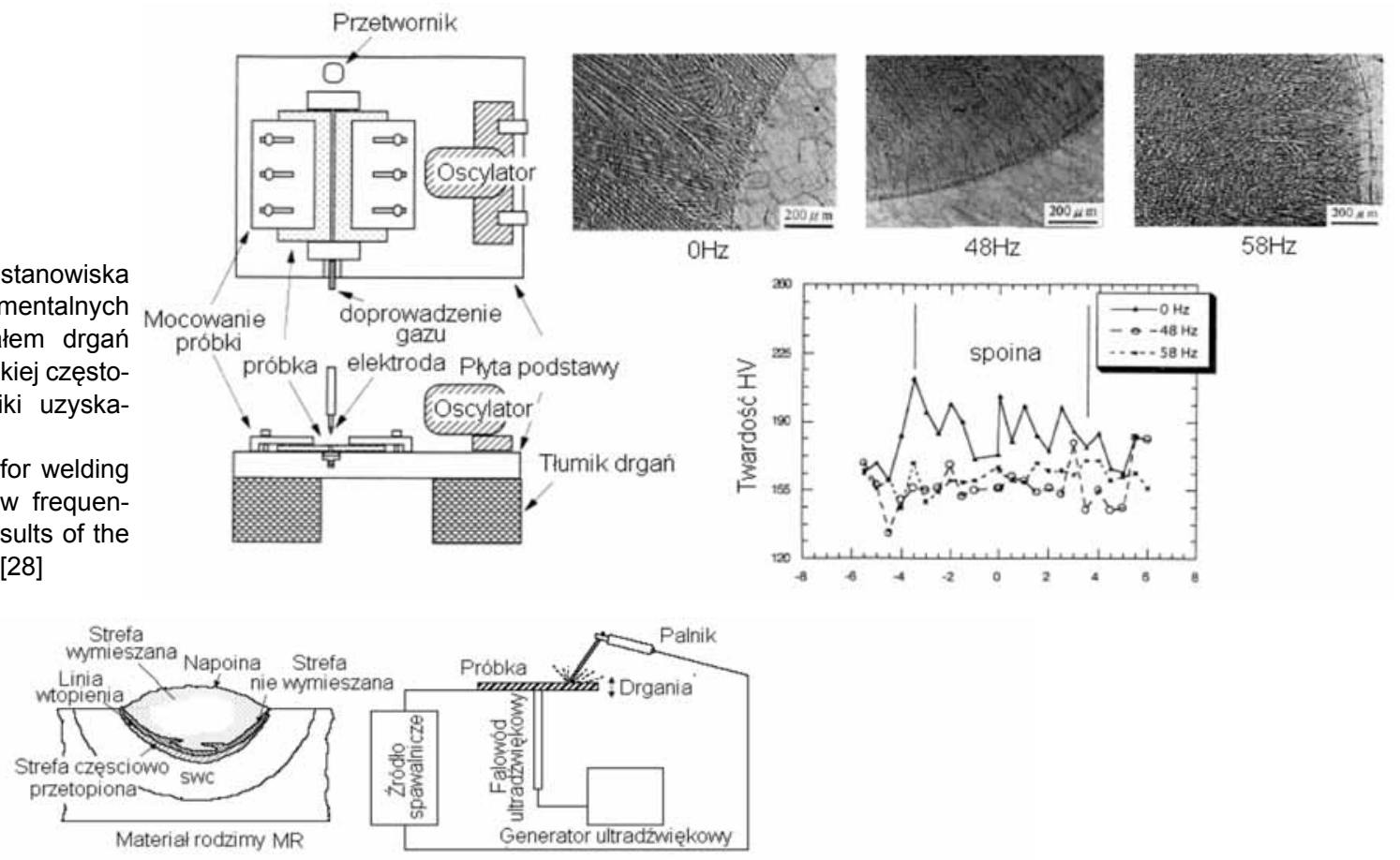
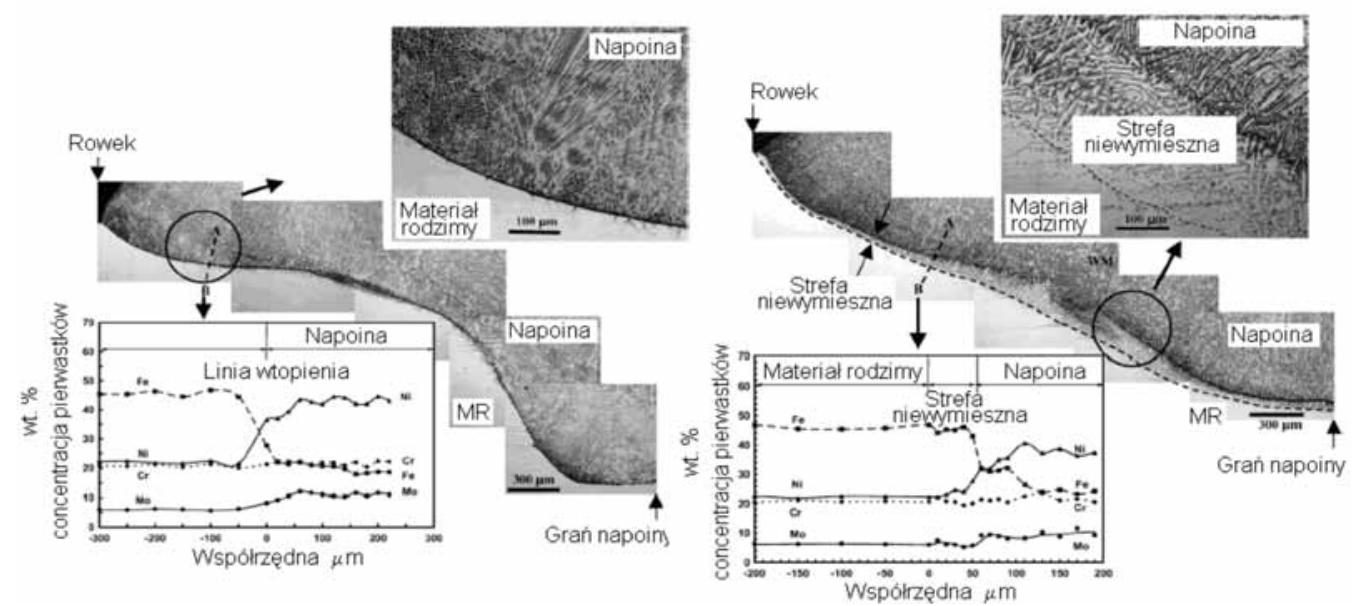

Rys. 4. Schemat eksperymentu spawania stali superaustenitycznej AL-6XN, skład chemiczny materiałów oraz wyniki uzyskanych badań [29]

Fig. 4. Idea of the austenitic steel AL-6XN welding experiment end research results [29] 


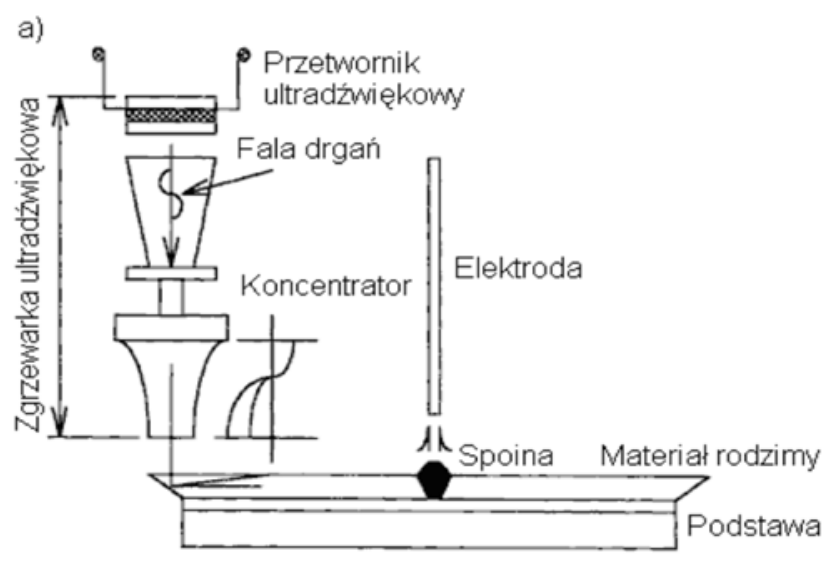

b)

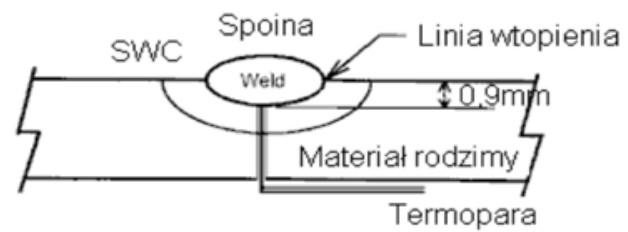

Rys. 5. Stanowisko badawcze do spawania stopu aluminium 7075-T6 ze wspomaganiem fal wprowadzanych pod kątem 30,45 i $60^{\circ}$ [30] Fig. 5. Statement for welding 7075-T6 aluminum alloy supported by a ultrasonic waves putted in by various angles 30,45 and $60^{\circ}$ [30]
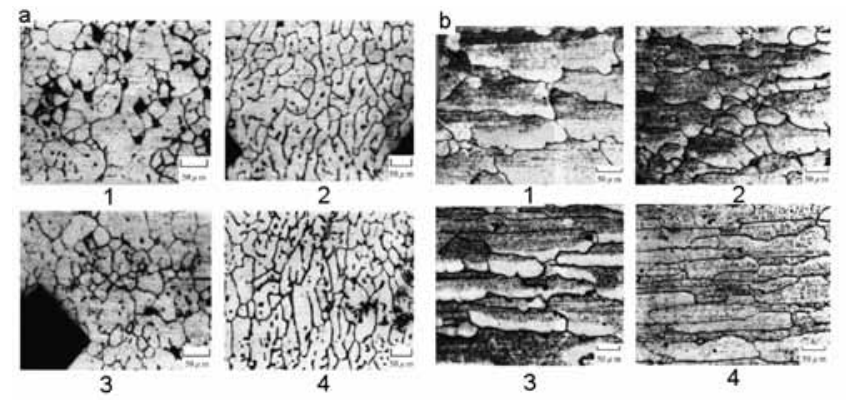

Rys. 6. Wielkość ziarna w stopie aluminium 7075-T6 spawanym z udziałem fali ultradźwiękowej o wysokiej mocy: a) strefa przegrzana, b) obszar w pobliżu linii wtopienia. Mikrografia 1 odpowiada złączu uzyskanemu bez ultradźwięków, a 2-4 z ich aplikacją dla właściwych kątów wejścia: 30, 45 i 60 [30]

Fig. 6. Grain size in 7075-T6 aluminum alloy welded with high power ultrasonic supporting wave: a) heat affected zone, b) border between melted and solid material. Picture no. 1 is corresponding to welding without vibration and pictures no. 2, 3, 4-with ultrasonic vibration putted in by various angles 30,45 and $60^{\circ}$ [30]

W literaturze opisano wpływ drgań ultradźwiękowych na proces łukowego napawania w osłonie gazowej (SMAW) stali superaustenitycznej AL-6XN w formie blachy o wymiarach $150 \times 60 \times 3 \mathrm{~mm}$ [29]. Materiałem dodatkowym był drut elektrodowy C-22 o średnicy $3,2 \mathrm{~mm}$. Proces spawania prowadzono przy następujących parametrach: $I=75 \mathrm{~A}, U=22 \mathrm{~V}$, prędkość napawania $v=30 \mathrm{~cm} / \mathrm{min}$ (rys. 4 ).

W wyniku zastosowania drgań częstotliwości $20 \mathrm{kHz}$ zaobserwowano, że strefa braku wymieszania spoiwa i materiału podłoża całkowicie przestała istnieć.

W literaturze przedstawiono też wyniki badań nad wpływem drgań ultradźwiękowych o dużym natężeniu na spawalność stopu aluminium 7075-T6 [30].
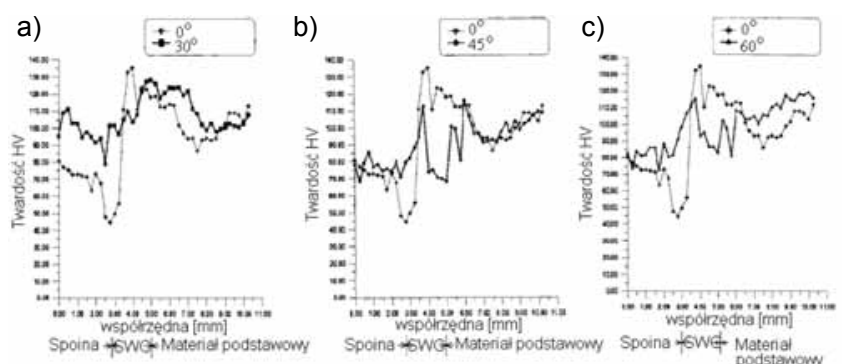

Rys. 7. Wpływ drgań ultradźwiękowych na twardość złączy spawanych ze stopu aluminium 7075-T6 ukosowanych pod różnymi kątami: a) 0 i $30^{\circ}$, b) 0 i $45^{\circ}$, c) 0 i $60^{\circ}[30]$

Fig. 7. Ultrasonic vibration influence on welded 7075-T6 aluminum alloy joints hardness for a various beveling angles of parent material: a) 0 and $30^{\circ}$, b) 0 and $45^{\circ}$, c) 0 and $60^{\circ}$ [30]

Głównym problemem przy spawaniu stopów jest obniżenie wytrzymałości w wyniku wzrostu wielkości ziarna oraz twardości, a także występowanie porowatości i pęknięć gorących. Wiele z tych niekorzystnych zmian metalurgicznych zachodzących w strefie wpływu ciepła może zależeć od przebiegu spawalniczego cyklu cieplnego. W niektórych przypadkach niekorzystne efekty oddziaływania tego cyklu można częściowo niwelować za pomocą odpowiedniej obróbki cieplnej, jednakże nie polepsza ona $w$ istotnym stopniu właściwości mechanicznych złączy.

W badaniach opisanych w pracy [30] wprowadzano drgania ultradźwiękowe, stosując zgrzewarkę ultradźwiękową. Drgania wprowadzano do specjalnie przygotowanego elementu spawanego metodą GTAW (rys. 5). Poprawę spawalności uzyskano wskutek zmiennej wartości naprężenia i odkształcenia podczas oddziaływania drgań ultradźwiękowych na powstające złącze spawane. Zbadano wpływ drgań ultradźwiękowych dużej mocy wprowadzanych pod różnymi kątami na cykl cieplny, temperaturę maksymalną i szybkość chłodzenia. Określono także wpływ drgań na wielkość ziarna, głębokość wtopienia i twardość. Do spawania użyto drutu 4043BY (Al-Si 0,5\%) o średnicy $2,5 \mathrm{~mm}$, a proces spawania realizowano $z$ prędkością $3,5 \mathrm{~mm} / \mathrm{s}$, stosując prąd spawania $180 \mathrm{~A}$ i napięcie łuku $75 \mathrm{~V}$. Drgania ultradźwiękowe wprowadzano falowodem o zarysie ekspotencjalnym podłączonym do generatora ultradźwiękowego firmy francuskiej MEGASONIC OMEGA_MPX II o mocy $2 \mathrm{~kW}$ i częstotliwości $20 \mathrm{kHz} z$ amplitudą wyjściową $3,6 \cdot 10^{-5} \mathrm{~m}$. Falowód wprowadzał drgania do próbki spawanego materiału wykonanej $z$ blachy aluminiowej o wymiarach $250 \times 150 \times 6 \mathrm{~mm}$. Strukturę otrzymanych złączy przedstawiono na rysunku 6.

Na rysunku 7 pokazano wyniki pomiarów twardości uzyskane dla różnych kątów ukosowania.

Ukosowanie elementów spawanych pod różnymi kątami podczas wprowadzania fal ultradźwiękowych powoduje efekty, które w różnym stopniu poprawiają strukturę ziarnową. W wyniku pomiarów temperatury w czasie przeprowadzanych eksperymentów sformułowano przypuszczenie, że odbita fala podłużna typu $L$ determinuje przekazywanie ciepła spowodowane 
szybkim transportem energii, a odbita fala poprzeczna typu $T$ wpływa na wytwarzanie się ciepła w efekcie rozpraszania energii i zmniejszania się lepkości ośrodka.

Szybkość i czas chłodzenia przybierają istotnie korzystniejsze wartości, ponieważ większa ilość ciepła może być szybciej odprowadzona dzięki propagacji fali. Sformułowano bardzo istotny wniosek, że możliwe jest osiągnięcie żądanej wartości szybkości chłodzenia i czasu chłodzenia w wyniku wprowadzania do powstającego złącza odpowiednich kontrolowanych rodzajów fal ultradźwiękowych.

W celu zwiększenia głębokości wtopienia należy zastosować wyższą wartość amplitudy odbitej fali poprzecznej i jednocześnie średnią wartość amplitudy odbitej fali podłużnej.

Zaobserwowano, że oddziaływanie drgań zwiększa efektywne przewodnictwo cieplne ciekłego metalu w jeziorku. Proces ten pomaga atomom w jeziorku przetrwać i wspomaga powstawanie ziaren o bardziej równomiernych kształtach i rozmiarach w strefie spoiny. Ponadto redukuje także skłonność do powstawania pęknięć gorących oraz wpływa na zmniejszenie rozmiarów ziaren w strefie spoiny.

$\mathrm{Na}$ podstawie badań sformułowano wniosek, że w celu uzyskania korzystnej struktury i zmniejszenia wielkości ziaren oraz obniżenia twardości w spoinie i SWC należy stosować możliwie największe wartości amplitud [30].

\section{Badania własne}

W ramach prac własnych wykonano liczne próby spawania materiałów wspomagane drganiami mechanicznymi [31, 32]. Drgania mechaniczne wprowadzano różnymi metodami i za pomocą różnych źródeł.

W jednej z prób zastosowano myjkę ultradźwiękową z przetwornikiem magnetostrykcyjnym wytwarzającą drgania o częstotliwości ok. $20 \mathrm{kHz}$, w której umieszczono materiał rodzimy, w innej zastosowano wibrator drgania niskiej częstotliwości ok. $50 \mathrm{~Hz}$. Do wprowadzania drgań mechanicznych zastosowano również generator ultradźwiękowy wyposażony w odpowiedni koncentrator i zakończony falowodem, na którym prowadzono próby spawania i zgrzewania rezystancyjnego. Wykonano następujące doświadczenia:

- napawanie elektrodą otuloną z udziałem ultradźwięków i drgań mechanicznych niskiej częstotliwości stali niskowęglowej,

- wtapianie laserem $\mathrm{CO}_{2}$ z zastosowaniem drgań ultradźwiękowych stali niskowęglowej,

- wtapianie laserem $\mathrm{CO}_{2}$ i TIG stopu PA6 z udziałem drgań ultradźwiękowych,

- wtapianie metodą TIG stali 45, stali austenitycznej i tytanu z udziałem drgań ultradźwiękowych,

- pulsacyjnezgrzewanierezystancyjneurządzeniem
Microwelder folii ze stali austenitycznej na podłożu ze stali 45 z udziałem drgań ultradźwiękowych.

Wyniki wymienionych wstępnych prac eksperymentalnych wykazały, że istnieje wpływ drgań niskiej częstotliwości oraz o częstotliwości ultradźwiękowej na budowę strukturalną napoin.

Charakter zmian struktury przejawia się w wielkości i kształcie ziaren oraz prawdopodobnie w różnicach ilościowego występowania różnych faz (wymaga to potwierdzenia innymi badaniami). Zaobserwować można, że zastosowanie drgań mechanicznych wpływa na zmniejszenie rozmiaru ziarna oraz czyni budowę strukturalną po krzepnięciu bardziej homogeniczną oraz wpływa na zmniejszenie występowania pęknięć gorących.

Zastosowanie drgań ultradźwiękowych podczas pulsacyjnego zgrzewania rezystancyjnego wpłynęło w niewielkim stopniu na zmiany struktury, choć uwidoczniły się w mikrostrukturze w większej ilości wysepek perlitycznych w stali 45 . Obserwuje się wzrost twardości w strefie przejściowej pomiędzy nakładaną folią a podłożem, a w obszarze jądra zgrzeiny twardość spada. Można zaobserwować lokalne strefy niszczenia połączenia folia-podłoże, będące odzwierciedleniem natury drgań mechanicznych, dlatego też wspomaganie drganiami procesu zgrzewania rezystancyjnego nie przynosi na obecnym etapie badań pożądanej poprawy właściwości mechanicznych i strukturalnych.

Z przeprowadzonych doświadczeń podczas wtapiania laserem na powierzchni tworzącej falowodu ultradźwiękowego wynika, że drgania ultradźwiękowe mają znaczący, ale różny wpływ na właściwości różnych stref złączy spawanych [32].

Wprowadzenie do złącza spawanego drgań ultradźwiękowych podczas krzepnięcia ma wyraźny wpływ na rozkład twardości w powstałym złączu. Jest on wyraźnie zależny od fazy, w jakiej znajdują się wprowadzane drgania ultradźwiękowe. Szczególnie widoczne jest to na granicy strefy wpływu ciepła i materiału rodzimego. W strefie przetopu widoczna jest zależność pomiędzy rozkładem naprężeń wywołanych drganiami a rozkładem twardości, choć nie jest ona już tak wyraźna. W miejscach gdzie w linii wtopienia pojawiły się nieciągłości przy przechodzeniu ze strefy wpływu ciepła (SWC) do materiału wtopiny, obserwuje się znaczny spadek twardości. Prawdopodobną przyczyną powstania nieciągłości jest wybrzuszenie się napoiny, co spowodowało obniżenie poziomu materiału w płynnym jeziorku spawalniczym na brzegach przy linii wtopienia. Podczas pomiaru twardości wzdłuż falowodu okazało się, że materiał rodzimy osiąga mniejszą twardość w punktach, w których wychylenie drgających cząstek podłoża jest największe, natomiast dla minimum wychylenia drgań obserwuje się wzrost twardości. 


\section{Podsumowanie}

Literatura w zakresie wspomagania drganiami mechanicznymi procesów spawalniczych nie jest zbyt obszerna. Na podstawie analizy dostępnych pozycji literaturowych trudno jest wysnuć jednoznaczne konkluzje, które z parametrów opisujących drgania i w jakim stopniu wpływają na poszczególne właściwości strukturalne i mechaniczne złączy spawanych. Brak jest jednoznacznych i precyzyjnych informacji na temat różnicowania wpływu rodzaju drgań na właściwości uzyskiwanych połączeń różnych materiałów. Nie są prezentowane również szczegółowe warunki, w jakich wprowadzane są drgania do złączy spawanych, brak jest też informacji na temat rzeczywistych widm czy przebiegów tych drgań w spawanych elementach. Mimo udokumentowania korzystnego wpływu drgań mechanicznych na właściwości złączy spawanych brak jest stanowiska w sprawie oddziaływań i zjawisk niekorzystnych z punktu widzenia procesu spawania i krzepnięcia spoin. Być może pokonanie problemów technicznych z wprowadzaniem drgań mechanicznych w gorącą strefę złączy spawanych będzie kluczowe dla ich zastosowania do kontrolowanego wspomagania procesów spawania.

Analiza literatury i wyniki przeprowadzonych do tej pory własnych prac badawczych wskazują na jakościową zależność parametrów opisujących drgania mechaniczne, budowę oraz właściwości struktur spawalniczych. W ramach planowanych prac badawczych istotne będzie określenie ilościowe wpływu parametrów drgań mechanicznych na struktury spawalnicze wybranych materiałów.

\section{Literatura}

[1] Matauschek J.: Technika ultradźwięków. WNT, Warszawa 1961.

[2] Sakwa W., Braszczyński J.: Wpływ ultradźwięków na grafityzację żeliwa ciągliwego. Mat. Konf. Sprawozdawczej Komitetu Hutnictwa PAN, Zakopane, 1964, zeszyt 3, s. 42.

[3] Braszczyński J.: Eiiet des ondes ultrasonores sur la graphitization de la fonte malleátale a coeur noir. Materiały XXXII MKO, Warszawa, 1964, s. 1-14.

[4] Braszczyński J.: Przegląd Mechaniczny, 8/1968, s. 230.

[5] Braszczyński J.: Sferoidyzacja wydzieleń węgla żarzenia i poprawa własności czarnego żeliwa ciągliwego na drodze wibracji infradźwiękowej. Materiały Konf. Sprawozd. Komitetu Hutnictwa PAN, Zakopane, 1968, Zeszyt 3, s. 86.

[6] Braszczyński J.: Archiwum Hutnictwa PAN, 2/1967, s. 331.

[7] Braszczyński J.: Przegląd Mechaniczny, 7/1966, s. 199.

[8] Braszczyński J.: Zeszyty Naukowe P. Cz., Odlewnictwo, 1966, Nr 8, s. 25.

[9] Braszczyński J., Mitko M.: Przegląd Odlewnictwa, 5/1976, s. 11.

[10] Braszczyński J.: Etude sur la germination du graphite peudant fecuit de la fonte blache pour mallèable. Materiały Konf. Journèes Mètallurgiques d'Automne. 1971, ref. 112, Paryż.

[11] Braszczyński J.: Metoda uvodenja ultrazvucnih valova u rastaljene metale. Materiały $\mathrm{V}$ Kongres Ljevaca Jugoslavije, 1977, Split (Jugosławia), ref. III, s. 1-16.

[12] Braszczyński J. i inni: Matematyczne metody planowania doświadczeń. Materiały Sympozjum MR-20. Wyd. Katedry Odlewnictwa Politechniki Częstochowskiej, 1968.

[13] Braszczyński J., Mitko M., Konopka Z., Tomczyński S.: Fonderie, 1982, $\mathrm{Nr} 20$, s. 23

[14] Mitko M., Braszczyński J.: Materiale science, 1-4/1982, Vd. VIII, s. 3.

[15] Braszczyński J., Konopka Z.: Giesserei-Forschung, 2/1983, s. 55.

[16] Braszczyński J., Swadowski J.: Rodzaje krystalizacji. Film dydaktyczno-naukowy. Politechnika Częstochowska, 1979.

[17] Braszczyński J., Mitko M., Konopka Z, Tomczyński S.: Wpływ drgań na krystalizację. Film naukowy. Politechnika Częstochowska, 1930.

[18] Braszczyński J.: Krystalizacia modelowej taveniny pod vpły- vom meschanickych kmitov (20-20000 Hz). Mat. Konf. Vysokopevne materiały - Nekonvencne Metalurgie, Bratysława (CSSR), 1983, Tom I, s. 98.

[19] Braszczyński J., Mitko M., Konopka Z., Tomczyński S.: Krzepnięcie metali i stopów, wyd. Ossolineum, Wrocław, 5/1981, s. 31.

[20] Braszczyński J.: Memoires Scient. Revue Metallurg, 1983, $\mathrm{Nr}$ I, s. 27.

[21] Liu Qingmei, Zhang Yong, Song Yoling, Qi Feipeng, Zhai Qijie: Influence of ultrasonic vibration on mechanical properties and microstructure of $1 \mathrm{Cr} 18 \mathrm{~N} 9 \mathrm{Ti}$ stainless steel, Materials and Design, 28, 2007, p. 1949-1952.

[22] Dalecki D., Raeman C. H., Child S. Z, Carstensen E. L.: Effects of pulsem ultrasound on the frog hart: III. The radiation force mechanism, Ultrasound in Medicine and Biology, 23, 1997, p. 275-85.

[23] Chaparro-Gonzales J., Mondragón-Sanchez L.: NunezAlcocer J., et al.: Application of an ultrasound technique to control the modification of Al-Si alloys, Mateer Des. 16, p. 47-50, 1995.

[24] Patent USA nr 4330699, 1982.

[25] Patent EP1559797A1, 2006.

[26] Russo W. Ł., Jefimow P. I.: Wlijanije wibracji niskich czastot na krystaliizaciju mietałła swarocznoj wanny i swojstwa metałła szwa, Swarocznoje Proizwodstwo nr 11, 1958.

[27] Russo W. Ł.: Wlijanije wibracji niskich czastot na krystaliizaciju mietałła w swarnom szwie, Sudostrojenije nr 4, 1958.

[28] Weite Wu: Influence of vibration frequency on solidification of weldments, Scripta mater. 42, 2000, p. 661-665.

[29] Y. Cui, C. L. Xu, Q. Han: Effect of ultrasonic vibration on unmixed zone formation, Scripta mater. 55, 2006 p. 975-978.

[30] Weng-Long Dai: Effects of high-intensity ultrasonic-wave emission on the weldability of aluminum alloy 7076-T6, Materials Letters 57, 2003 p. 2447-2454.

[31] Krajewski A.: Wspomaganie procesów spawalniczych drganiami mechanicznymi, Zeszyt Naukowy nr 229, s. 33-51 (seria Mechanika), pt. Innowacje w technikach spajania, Oficyna Wydawnicza Politechniki Warszawskiej, 2009.

[32] Krajewski A.: Badanie wpływu pola ultradźwiękowego na budowę i własności struktur spawalniczych, Zeszyt Naukowy nr 230, s. 71-82 (seria Mechanika), pt. Spajanie Materiałów we współczesnej technice, Oficyna Wydawnicza Politechniki Warszawskiej, 2010. 